\title{
A Jew's Jew: Paul and the Early Christian Problem of Jewish Origins*
}

\author{
Andrew S. Jacobs / University of California, Riverside
}

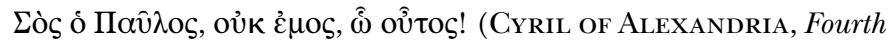 \\ Paschal Letter)
}

No one wants an apostle riddled with contradictions. (JoHN G. GAGER, Reinventing Paul)

PAUL, THE ARCHETYPAL JEW

In recent decades the Historical Paul has begun to catch up with (and perhaps even outstrip) the much-buffeted Historical Jesus as a heated nexus of historical and theological debate about Christianity's Jewish origins. ${ }^{1}$ The so-called New Perspective on Paul, ${ }^{2}$ an array of historicotheological positions united (roughly) by a reconsideration of Paul's

\footnotetext{
* I wish to thank the anonymous readers for the Journal of Religion who provided consistently sound advice on matters both historical and stylistic. The following abbreviations are used for critical editions, followed by volume and page numbers: CCL = Corpus Christianorum, series Latina (Turnhout: Brepols, 1954-); CSEL = Corpus scriptorum ecclesiasticorum latinorum (Vienna: Akademie Verlag, et al., 1866-); GCS = Griechischen christlichen Schriftsteller (Leipzig: J. C. Hinrichs, etc., 1899-); LCL = Loeb Classical Library (Cambridge, MA: Harvard University Press, 1912-); PG = Patrologia Graeca, ed. J.-P. Migne (Paris: Migne, 1857-66); PL = Patrologia Latina, ed. J.-P. Migne (Paris: Migne, 1844-65); SC = Sources chrétiennes (Paris: Editions du Cerf, 1943-).

${ }^{1}$ Brendan Byrne, "Interpreting Romans Theologically in a Post-'New Perspective' Perspective," Harvard Theological Review 94 (2001): 227-41; John G. Gager, Reinventing Paul (Oxford: Oxford University Press, 2000), 43-75; James D. G. Dunn's "Introduction," and "In Search of Common Ground," both in Paul and the Mosaic Law, ed. James D. G. Dunn (Grand Rapids, MI: Eerdmans, 2001), 1-5, 309-34; James D. G. Dunn, "Introduction," in The Cambridge Companion to St. Paul, ed. James D. G. Dunn (Cambridge: Cambridge University Press, 2003), 1-15 at 9-12; Ben Witherington III, "Contemporary Perspectives on Paul," in Dunn, Cambridge Companion, 256-69.

${ }^{2}$ The label derives from the 1982 Manson Memorial lecture delivered by James D. G. Dunn, first published as "The New Perspective on Paul," Bulletin of the John Rylands Library 65 (1983): 95-122 and reprinted with an additional note in Jesus, Paul, and the Law: Studies in Mark and Galatians (Louisville, KY: Westminster/John Knox, 1990), 183-214; now the term encompasses a wide array of positions on Paul's beliefs and motives.

(C) 2006 by The University of Chicago. All rights reserved.

$0022-4189 / 2006 / 8602-0004 \$ 10.00$
} 


\section{Paul and the Problem of Jewish Origins}

Jewish context, ${ }^{3}$ has sought to reconfigure the apostle apart from centuries of alleged misreading and misappropriation. ${ }^{4}$ Distinctly modern ethical claims are bound up in the New Paul. Much like the Historical Jesus of the most recent "quest," ${ }^{5}$ the Paul of the New Perspective has recaptured his Jewish roots and thus disarmed theologians seeking to secure anti-Jewish advantage through his various pronouncements against the "law" and "works." ${ }^{6}$ Opponents of this New Perspective seek to preserve the distinctiveness of the earliest apostolic kerygma in direct continuity with the originality of Jesus's message. ${ }^{7}$ When Paul speaks against the law and in favor of "justification by faith," he is a new man in a new covenant and opposing those Jews who still insist on adherence to one old model of salvation. ${ }^{8}$ Paul himself bears witness to the theological weakness of this old Jewish soteriology in his more polemical writings (especially Romans, Galatians, and Philippians). ${ }^{9}$

Both the New Perspective Pauline scholars and the anti-, post-, or non-New Perspective scholars see the Historical Paul emerging clearly

\footnotetext{
${ }^{3}$ See Kirster Stendahl's groundbreaking critique of the "traditional" view, identified as a trajectory moving from Augustine through Luther into modern Protestant interpretations: "The Apostle Paul and the Introspective Conscience of the West," Harvard Theological Review 56 (1963): 199-215, reprinted in The Writings of St. Paul, ed. Wayne A. Meeks (New York: Norton, 1972); more recently, Stanley K. Stowers, A Rereading of Romans: Justice, Jews, and Gentiles (New Haven, CT: Yale University Press, 1994).

${ }^{4}$ E. P. Sanders's outline of "covenantal nomism" is found in Paul and Palestinian Judaism: A Comparison of Patterns of Religion (Philadelphia: Fortress, 1977), summarized on 419-28 and 511-23; its overarching attempt to reconfigure Second Temple Judaism, and Paul's relationship to it, is arguably one of the common links most New Perspective scholars share. For a recent critique of Sanders's description of "covenantal nomism" based on a reexamination of available Jewish sources from this period, see D. A. Carson, Peter T. O'Brien, and Mark A. Seifrid, eds., Justification and Variegated Nomism: A Fresh Appraisal of Paul and Second Temple Judaism, vol. 1, The Complexities of Second Temple Judaism (Grand Rapids, MI: Baker Academic, 2001).

${ }^{5}$ See Paula Fredriksen, Jesus of Nazareth, King of the Jews: A Jewish Life and the Emergence of Christianity (New York: Knopf, 1999); and Donal Harman Akenson, Saint Saul: A Skeleton Key to the Historical Jesus (New York: Oxford University Press, 2000), 3: "In the present day Quest for the Historical Jesus, the single most repeated assertion of his substance is that Jesus was Jewish."

${ }^{6}$ See Gager, Reinventing Paul, 150-51.

${ }^{7}$ Seyoon Kim, Paul and the New Perspective: Some Thoughts on the Origin of Paul's Gospel (Grand Rapids, MI: Eerdmans, 2002), 82-83 and 259-90, and "The Jesus Tradition in 1 Thess. 4.13-5.11," New Testament Studies 48 (2002): 225-42.

${ }^{8}$ Charles H. Talbert, "Paul, Judaism, and the Revisionists," Catholic Bible Quarterly 63 (2001): 1-22, at 20: "Paul, then, fits into the Christian-Jewish messianic way of thinking about a new covenant that replaces the old, inefficacious one."

${ }^{9}$ Often, critics of the New Perspective reevaluate Sanders's "covenantal nomism": see, e.g., Timo Eskola, Theodicy and Predestination in Pauline Soteriology, Wissenschaftliche Untersuchungen zum Neuen Testament 2/100 (Tübingen: Mohr-Siebeck, 1998), 15-21, 52-60, 267-75; Kim, Paul, who complains about covenantal nomism being raised "to the level of dogma" (57 n. 193, 83); and D. A. Carson, "Introduction," and "Summaries and Conclusions," in Carson et al., Justification and Variegated Nomism, 1-5, 543-48.
} 


\section{The Journal of Religion}

from the concerns of the Judaism of his day. Paul comes to stand simultaneously both as paradigmatic Jew, a prime source for understanding the nature of Jewish religion and community in the first century $\mathrm{CE},{ }^{10}$ and as paradigmatic Christian (to speak anachronistically), highlighting the superiority of his new faith to nonbelieving contemporaries who, as yet, refused the faith of Jesus. This doubled nature of Paul's Jewishness in his writings creates a productive-and yet, perhaps, ultimately irresolvable-tension at the very origins of Christianity. If Paul speaks Jewishly, then what is new about the new covenant? ${ }^{11}$ If Paul speaks anti-Jewishly, then what is to prevent his followers from committing acts of theological, verbal, or physical violence against Jews? ${ }^{12}$ Perhaps appropriately for one who claimed to become "all things to all people" (1 Cor. 9:22), Paul must speak by turns Jewishly and non-Jewishly. The resulting discourse of religious identity emerges, in the twentyfirst century, as theologically, historically, and ethically fractured.

That divisive interpretations of Paul's simultaneous Jewishness and non-Jewishness should emerge from his already-contentious writings would certainly come as no surprise to Paul's ancient interpreters. Consider an incident in the late fourth century, when an up-and-coming North African priest, Augustine, wrote to the well-established ascetic homme de lettres Jerome in Bethlehem to voice some concerns regarding Scripture and the apostles. ${ }^{13}$ After expressing unease with Jerome's new translations of the Bible iuxta Hebraeos, Augustine protested Jerome's interpretation of the apostolic showdown concerning the observance of Jewish law in Galatians 2 as mere "playacting" (simulatio) between Peter (Cephas) and Paul. ${ }^{14}$ Augustine feared that Jerome would pro-

${ }^{10}$ Talbert, "Paul,” 11-12; Kim, Paul, 293-95.

${ }^{11}$ Byrne, "Interpreting Romans Theologically," 230-32.

${ }^{12}$ This post-Holocaust theological position is clearly the stake for such New Perspectivist readers. See, among others, Lloyd Gaston, Paul and Torah (Vancouver: University of British Columbia Press, 1987), 2-5, 34; and Gager, Reinventing Paul, 17-19, 150-52. Of course, opponents of the New Perspective are often equally clear and sincere in their attempts to avoid the sort of anti-Jewish readings of Paul that flow into outright anti-Semitism: see Frank Thielman, Paul and the Law: A Contextual Approach (Downer's Grove, IL: InterVarsity Press, 1994), 46-47; and Kim, Paul, 61-62 n. 212.

${ }^{13}$ Ralph Hennings, Der Briefwechsel zwischen Augustinus und Hieronymus und ihr Streit um den Kanon des Alten Testaments und die Auslegung von Gal. 2, 11-14, Supplements to Vigiliae Christianae 21 (Leiden: Brill, 1994); and Alfons Fürst, Augustins Briefwechsel mit Hieronymus, Jahrbuch für Antike und Christentum Ergänzungsband 29 (Münster: Aschendorffsche Verlagsbuchhandlung, 1999). Augustine initiated the correspondence, which lasted for several years, before his elevation to the episcopacy.

${ }^{14}$ On early and modern conflation and separation of "Cephas" (Gal. 2:9, 11, 14) and "Peter" (Gal. 2:7, 8), see Bart D. Ehrman, "Cephas and Peter," Journal of Biblical Literature 109 (1990): 463-74; and the response by Dale C. Allison, "Peter and Cephas," Journal of Biblical Literature 111 (1992): 489-94. 


\section{Paul and the Problem of Jewish Origins}

vide heretics with fuel to argue the unreliability and inconsistency of the entire Scripture if it might be found that, at times, the Bible lies. ${ }^{15}$

Augustine's queries, particularly surrounding Jerome's interpretation of Galatians $2,{ }^{16}$ initiated a tumultuous trans-Mediterranean debate energized by a common ancient Christian anxiety: the haunting Jewish origins of Christianity. As in the twenty-first-century debates over the New Paul, history and theology collided in antiquity to produce fractious and highly contested understandings of what Paul's Jewishness might mean in the working out of Christian identity. Jerome, for example, found Augustine's suggestion that the two premier apostles of Christ might actually debate the merits of the continued performance of Jewish law to be deeply offensive, particularly when Augustine casually remarked that "Paul was a Jew": "Wretched and most pitiable," Jerome sneers, "are those people who, for contention and love of the Law that has been abolished, have made Christ's Apostle into a Jew!"18

Early Christians felt the anxiety of their originary Jewishness acutely. ${ }^{19}$ In the second and third centuries, they often struggled to find a palatable middle ground between a useful and significant Jewish past and a distinctive Christian present. Too much Jewishness, through preference for the Old Testament over the gospels or continued adherence to Jewish ritual law, could be labeled "Judaizing" heresy. ${ }^{20}$ By

\footnotetext{
${ }^{15}$ Augustine, epistle (hereafter, "ep.") 28.2-3 (CSEL 34.1:109-10); such concerns lie at the heart of Augustine's anti-Manichean texts: see, e.g., Contra Faustum Manichaeum 32.7 (PL 42: 500-501).

${ }^{16}$ Jerome puts forward the idea that Peter and Paul were playacting before the Antiochenes in his Commentarius in epistolam ad Galatas 1.2.11-13 (PL 26:338-41). Jerome did not invent this interpretation, which preserves the harmony of the two primary apostles of the New Testament, nor was it considered especially controversial in the fourth century: see Fürst, Augustins Briefwechsel, 2-64, esp. 29-36, on Gal. 2:11-14 as simulatio or ن́лóкрıбı૬.

${ }_{17}$ Augustine, ep. 40.4.4 (CSEL 34.2:73), cited by Jerome, ep. 112.14.1 (CSEL 55:382): Iudaeus erat [Paulus]. See the analysis, which differs slightly from my own, of Paula Fredriksen, "Secundem Carnem: History and Israel in the Theology of St. Augustine," in The Limits of Ancient Christianity: Essays on Late Antique Thought and Culture in Honor of R. A. Markus, ed. William Klingshirn and Mark Vessey, Recentiores: Later Latin Texts and Contexts (Ann Arbor: University of Michigan Press, 1999), 26-41, at 37-39.

${ }^{18}$ Jerome, ep. 112.17 (CSEL 55:387).

${ }^{19}$ An anonymous reader for the Journal of Religion queried my use of the somewhat obsolete "originary" instead of the more commonplace "original." Since the adjective "original" has come to signify identity and authenticity (an "original" vs. "copies"), I have resurrected this older adjective to signify "evocative of origins."

${ }^{20}$ See, e.g., concerns of Ignatius of Antioch, ep. ad Magnesios 8-10, ep. ad Philadelphienses 6 (SC 10:68-90, 124-5); Shaye J. D. Cohen, "Judaism without Circumcision and 'Judaism' without 'Circumcision' in Ignatius," Harvard Theological Review 95 (2002): 395-415; and the various heresiological sources on "Jewish-Christians" collected by A. F. J. Klijn and G. J. Reinink in their Patristic Evidence for Jewish-Christian Sects, Supplements to Novum Testamentum 36 (Leiden: Brill, 1973).
} 


\section{The Journal of Religion}

contrast, too little Jewishness, most spectacularly represented by Marcion's expurgated Scriptures, or Gnostic rejection of the Old Testament God of Israel as an evil demiurge were likewise rejected. ${ }^{21}$ Throughout late antiquity, it seems, mainstream Christianity was content neither to reject nor to embrace fully its Jewish origins.

Also parallel to the modern debates over the Historical Paul in this ancient anxiety is the theological and ethical conundrum posed by the persistence of Jews in the social spaces in which Christians lived. ${ }^{22}$ Modern interpreters of Paul evince concern over the potential for antiSemitism to be found in certain readings of Paul's opposition to Jews and Judaism. Ancient Christians, unburdened by such interfaith niceties, nonetheless sensed an acute challenge to their increasingly triumphalist theological posture in the ongoing and exasperating presence of those thorough unbelievers, the Jews. "Real" Jews aggravated concerns over originary Jewishness among Christian communities already jostling internally for precise comprehension of theology, history, and exegetical truth.

Enter the apostle Paul. Just as for those modern scholars, historians, and theologians who debate the New Perspective on Paul, ancient Christian scholars, historians, and theologians found in Paul a compelling, and confounding, paradox of difference and sameness, a "variable and many-sorted man" who might speak to Christian concern about Jewish roots. ${ }^{23}$ The fourth and fifth centuries, in particular, witnessed a heightened interest in the figure of Paul, a sort of late ancient "century of Saint Paul," during which "the Apostle" was pressed for

\footnotetext{
${ }^{21}$ The classic pervasively (but not uniformly) anti-Jewish Christian defense of the Old Testament against Marcion is Tertullian's Adversus Marcionem. See Adolf von Harnack, Marcion: Das Evangelium vom Fremden Gott, Texte und Untersuchungen zur Geschichte der altchristlichen Literatur 45, 2nd ed. (Leipzig: Heinrichs, 1924); Stephen G. Wilson, "Marcion and the Jews," in Anti-Judaism in Early Christianity, ed. Stephen G. Wilson, Studies in Christianity and Judaism 2 (Waterloo: Laurier, 1986), 2:45-58; and Heikki Räisänen, "Marcion and the Origins of Christian Anti-Judaism," Temenos 33 (1997): 121-35. Interestingly, R. Joseph Hoffman (Marcion, On the Restitution of Christianity: An Essay on the Development of Radical Paulinist Theology in the Second Century [Chico, CA: Scholars Press, 1984], 229-34) suggests that Marcion's radical excision of the Jewish God and Savior from his Christianity actually allowed for a more "proJewish" theology than that found in his Paulinist opponents.

${ }^{22}$ The vitality of ancient Judaism is the central concern of Marcel Simon's classic Verus Israel: A Study in the Relations between Christians and Jews in the Roman Empire (135-425), trans. H. McKeating (Oxford: Oxford University Press, 1986). We should beware, however, of viewing Christian anxiety over Jews as simply a reactionary posture, responding to Jewish persecution or religious competition for proselytes: see Miriam S. Taylor, Anti-Judaism and Early Christian Identity: A Critique of the Scholarly Consensus, Studia Post-Biblica 46 (Leiden: Brill, 1995).

${ }^{23}$ The phrase of John Chrysostom, De laudibus sancti Pauli 5.4, 6 (SC 300:238, 242): локќ́ $\lambda$ o

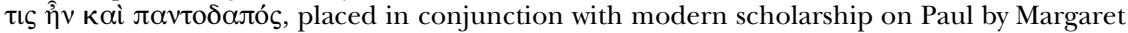
M. Mitchell, “'A Variable and Many-Sorted Man': John Chrysostom's Treatment of Pauline Inconsistency," Journal of Early Christian Studies 6 (1998): 93-111.
} 


\section{Paul and the Problem of Jewish Origins}

answers on ascetic virtue, ecclesiastical discipline, and human participation in salvation. ${ }^{24}$ The contentious and vexing question of the Jewish origins of Christianity seemed particularly suitable to the apostle's "variable" voice in this period. He was authoritatively Christian, "the Apostle to the Gentiles," decisively instructing his non-Jewish readers in the fourth and fifth centuries on the deficiency of the law and the

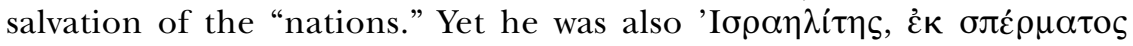

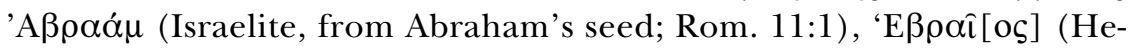

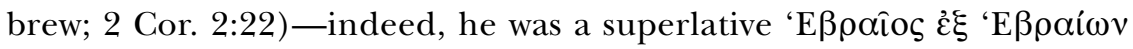
(Phil. 3:5), often translated as "a Hebrew born of Hebrews" or, perhaps more colloquially, "a Jew's Jew." 25

Paul's hyper-Jewish epithet in Philippians was especially favored by late ancient Christians in order to come to terms with Judaism's compelling otherness. While inveighing against "those who mutilate the flesh" (circumcisers), ${ }^{26}$ Paul argued from his own Jewishness: ${ }^{27}$ "If anyone else has reason to be confident in the flesh, I have more: circumcised on the eighth day, a member of the people of Israel, of the tribe of Benjamin, a Hebrew born of Hebrews; as to the law, a Pharisee; as to zeal, a persecutor of the church; as to righteousness under the law, blameless. But whatever gain I had, I counted it a loss on account of Christ" (Phil. 3:4-7). Here, as in other letters (see Romans 11 and 2 Corinthians 2), Paul draws on his Jewish credentials, in a rising crescendo, in order to score points against his opponents who, presumably, also presented themselves as Jewish experts in order to persuade Gentile Christians to be circumcised. Most modern interpreters view Paul's

\footnotetext{
${ }^{24}$ Thomas F. Martin, "Vox Pauli: Augustine and the Claims to Speak for Paul, an Exploration of Rhetoric at the Service of Exegesis," Journal of Early Christian Studies 8 (2000): 237-72, esp. 238-42 and nn. (Martin coins "century of Saint Paul" on 241). See also Maurice Wiles, The Divine Apostle: The Interpretation of St. Paul's Epistles in the Early Church (Cambridge: Cambridge University Press, 1967), esp. 3-13; Maria Grazia Mara, "Commentaries on the Pauline Epistles," and E. Dassman, "Paulinism," both in Encyclopedia of the Early Church, ed. Angelo di Berardino, trans. Adrian Walford (New York: Oxford University Press, 1992), 657-59; and Margaret M. Mitchell, Heavenly Trumpet: John Chrysostom and the Art of Pauline Interpretation, Hermeneutische Untersuchungen zur Theologie 40 (Tübingen: Mohr-Siebeck, 2000), 66-67.

${ }^{25}$ Edgar Goodspeed, Problems of New Testament Translation (Chicago: University of Chicago

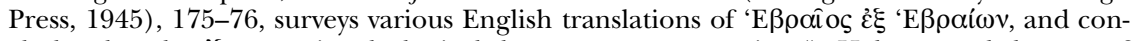
cludes that the $\hat{\varepsilon} \xi$ must signal physical descent, even suggesting "a Hebrew, and the son of Hebrews." In addition to indicating origin, however, the genitive might also indicate a superlative, on analogy with the Hebrew superlative (viz., "song of songs," "Lord of Lords")

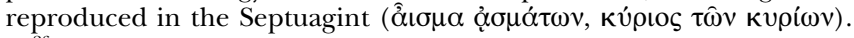

${ }^{26}$ On Paul's opponents in Philippians, see A. F. J. Klijn, "Paul's Opponents in Philippians III," Novum Testamentum 7 (1964): 278-84, who proposes that Paul was reacting to strictly Jewish missionaries. By contrast, Fabian E. Udoh ("Paul's Views on the Law: Questions about Origin [Gal. 1:6-2:21; Phil. 3:2-11]," Novum Testamentum 42 [2000]: 214-37), argues that Paul is still responding to his Galatian foes (223 nn. 33-34).

${ }^{27}$ On Paul's rhetoric in general in this letter, see Udoh, "Paul's Views."
} 


\section{The Journal of Religion}

particular rhetorical flourish here as a sort of superlative a fortiori argument: "If it [i.e., adherence to the law] is out of court for Paul, the archetypal Jew, it must be out of court for his Gentile Philippian followers," one commentator notes. ${ }^{28}$ Paul, more than any other firstcentury Jew, understands what he gave up through Christ ${ }^{29}$ and can therefore trump the Judaizing arguments of his opponents at Philippi.

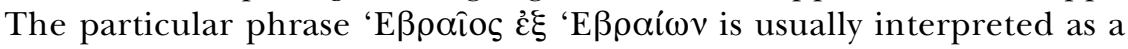
claim either to linguistic or ethnic superiority, or both at once. Paul's real Jewishness is seen as a matter of scriptural and ritual authenticity ("tradition"), ${ }^{30}$ an undiluted "Hebraism" due to his Jerusalemite formation as a Pharisee. ${ }^{31}$ In this one passage we hear both of Paul's voices: his claim to superiority in Judaism (by which he can "out-Jew" his opponents) and to superiority apart from Judaism (by which he can recapture the theological loyalties of the Gentile Philippians).

The perception of Paul's voice as doubled-simultaneously Jewish and non-Jewish-was captured by early Christian exegetes in order to articulate the perplexing religious boundaries of Judaism and Christianity in late antiquity. Below I explore two modes by which early Christians exploited Paul's superlative Jewishness, as a "Hebrew of Hebrews," in order to confront their troubling Jewish origins: through direct exegesis of Paul's Philippians boasting and by taking up and casting his epithet onto other significant figures of Jewish history. In both instances of oratory engagement with Paul's most Jewish voice, we see how Christians engaged the anxiety of Jewish otherness at the

\footnotetext{
${ }^{28}$ Peter Oakes, Philippians: From People to Letter, Society for the New Testament Monograph Series 110 (Cambridge: Cambridge University Press, 2001), 112; see also 111, where Oakes refers to Paul's "impeccable Jewish privileges." Similar, older, traditional views are expressed in Marvin R. Vincent, ed., A Critical and Exegetical Commentary on the Epistles to the Philippians and to Philemon, The International Critical Commentary (Edinburgh: Clark, 1897), 96-98; and

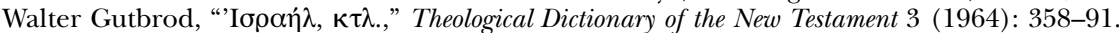

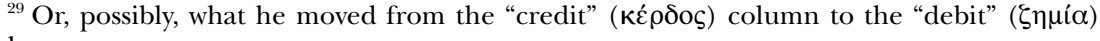
column.

${ }^{30}$ William F. Orr and James Arthur Walther, 1 Corinthians, The Anchor Bible (New York: Doubleday, 1976), 3; see also Klaus Haacker, "Paul's Life," in Dunn, Cambridge Companion, 21.

${ }^{31}$ James D. G. Dunn ("Who Did Paul Think He Was? A Study of Jewish-Christian Identity," New Testament Studies 45 [1999]: 174-93, at 185-87) insists that simple linguistic identification must be supplemented by religious "conservatism" (drawing, in part, on the work of Graham Harvey, The True Israel: Uses of the Names Jew, Hebrew and Israel in Ancient Jewish Literature and Early Christian Literature, Arbeiten zur Geschichte des Antiken Judentum und des Urchristentums 35 [Leiden: Brill, 1996]). The emphasis on linguistic heritage (esp. as a marker of "Palestinian Judaism") is troubled by such comments as the following from Paula Fredriksen (From Jesus to Christ, 2nd ed. [New Haven, CT: Yale University Press, 2000], 55): "If Acts did not exist and all we had were Paul's letters, we would have no reason to think of him as other than a Jew of the Diaspora whose language was Greek." See also her "Judaism, the Circumcision of Gentiles, and Apocalyptic Hope: Another Look at Galatians 1 and 2," Journal of Theological Studies, n.s., 42 (1991): 532-64.
} 


\section{Paul and the Problem of Jewish Origins}

heart of their own religious identity through deft gestures of simultaneous appropriation and repudiation. I focus especially on appropriations of Paul's doubled voice through this epithet in the fourth and fifth centuries, that is, the period of the nascent Christian Empire: as I have argued elsewhere, and will suggest again in the conclusion of this essay, the contours of Jewish-Christian relations in the period of the early Christian Roman Empire were especially suited to this complex Christian approach to Jewish otherness.

\section{SPEAKING IN PAUL'S JEWISH VOICE}

Ancient commentators during the century of Paul (the late fourth to fifth centuries) relished the way the apostle piled high his archetypal Jewish credentials in his letter to the Philippians. Paul provided ancient readers with a crucial witness to the theological and historical character of Judaism. They learned, for instance, from Paul's hyperbolic Jewish testimony in Philippians 3:5-7 that Jews are inimitably carnal in their religious orientation. Since "his person was in every way Jewish, by circumcision, by people [genere], by tribe, by family [gente], by law, by adherence to the law [administratione in lege], and by zealous way of life [studio etiam vitae]," it can be concluded that "Jews maintain confidence in the flesh, even especially in the flesh." ${ }^{2}$ Because of its authority, Paul's rhetoric also provided an opportunity for Christians to speak authoritatively to the pressing issue of their own Jewish origins. Paul, therefore, was a touchstone of Jewish and Christian truth for the Christian exegete.

Most commentators found a way to combine these superlatively Jewish and Christian voices. More rare were exegetes who strove to eliminate Paul's Jewishness entirely in order to highlight what they perceived as his universalist (and supersessionist) preaching. One such rare interpreter was the mysterious Roman exegete known as Ambrosiaster (so named for his similarity to the more famous Ambrose of Milan). ${ }^{33}$ Ambrosiaster is notable as an early voice in this century of

\footnotetext{
${ }^{32}$ Marius Victorinus, Liber in epistulam ad Philippenses 3:4/7, text in Marius Victorinus: Commentarii in Apostolum, ed. Albrecht Locher (Leipzig: Teubner, 1972), 99-100. This comes from the earliest extant Latin commentary on Paul's letters (although a partial commentary): see Alexander Souter, The Earliest Latin Commentaries on the Epistles of St. Paul (Oxford: Clarendon, 1927), 8-38.

${ }^{33}$ The classic study of this figure remains Alexander Souter, A Study of Ambrosiaster, Texts and Studies 8.4 (Cambridge: Cambridge University Press, 1905). See also the comments of Annelie Volgers, "Ambrosiaster: Persuasive Powers in Progress," in Erotapokriseis: Early Christian Question-and-Answer Literature in Context, Proceedings of the Utrecht Colloquium, 13-14 October 2003, ed. Annelie Volgers and Claudio Zamagni, Contributions to Biblical Exegesis and Theology 37 (Leuven: Peeters, 2004), 99-125.
} 


\section{The Journal of Religion}

$\mathrm{Paul}^{34}$ who attempted to deploy the apostle in order to construct more careful boundaries against the religious "others" of his day, particularly "pagans," heretics, and Jews. ${ }^{35}$ Indeed, his attention to Jews was so notable that scholars have imagined Ambrosiaster himself may have been a convert from Judaism, eager to displace his former religion. ${ }^{36} \mathrm{Am}-$ brosiaster's attention to both Judaism and Paul, however, may be a sign more of the anxiety attendant upon Christianity's Jewish origins than a psychological scar of personal conversion. Judaism provided a theological stumbling block to Christian superiority, and Paul provided a solution to this problem.

Ambrosiaster begins his comments on Philippians 3:5 with a rather recondite piece of philology that allows him to transform the seemingly hyper-Jewish epithet "Hebrew of Hebrews" (Hebraeus ex Hebraeis in Latin) from a linguistic and ethnic marker of religious particularity into a claim of universalizing, Christian faith. Ambrosiaster argues that the patronymic Hebraeus does not derive from Abraham's ancestor Eber (Gen. 10:24-25, 11:14-17), as, Ambrosiaster remarks, "many people suppose." ${ }^{37}$ Instead, Hebraeus derives from Abraham, with the linguistically common alteration of a single phoneme: Abraei to Hebraei. ${ }^{38}$ So when Paul calls himself a "Hebrew of Hebrews," he is indeed choosing a surname (cognomen) as a "testimony to the nobility of his birth" (testimonium enim nobilitas generis erat) - it is simply not a Jewish birth he is claiming. Paul does not boast of physical descent from the obscure ethnic progenitor of the Jews, ${ }^{39}$ but rather from Abraham.

\footnotetext{
${ }^{34}$ Ambrosiaster leaves one of the earliest complete commentaries on Paul's letters (minus Hebrews), some decades after Marius Victorinus's commentaries on Galatians, Ephesians, and Philippians: see Souter, Earliest Latin Commentaries, 39-95.

${ }^{35}$ See Souter, Study, 161-74 on Ambrosiaster's likely date (366-82 CE) and location (Rome). On his polemical interests, see Franz Cumont, "La polémique de l'Ambrosiaster contre les païens," Revue d'Histoire et de Littérature Religieuses 8 (1903): 417-40; L. Speller, "Ambrosiaster and the Jews," Studia Patristica 17.1 (1982): 72-8; and Souter, Study, 180-83.

${ }^{36}$ Speller ("Ambrosiaster," 72-73) gives an overview of this theory (originating with Dom G. Morin in 1899) and its origins and problems. In short, attention to Jews in this period can be explained in many ways other than an author's personal history (Jerome is the prime counterwitness here).

${ }^{37}$ Ambrosiaster, Commentarius in epistolam ad Philippenses 3:5/7 (CSEL 81.3:153), Liber quaestionum 108.2 (CSEL 50:522). See, e.g., Jerome, Liber Hebraicorum quaestionum in Genesim 1.10.24 (PL 23:955): Heber, a quo Hebraei. Jerome's assumption was, of course, plausible, since the name עברי עבר is likely a retroverted eponym for Francis Brown, The New Brown-DriverBriggs-Genesius Hebrew and English Lexicon (Peabody, MA: Hendrickson, 1979), 720.

${ }^{38}$ Ambrosiaster, Commentarius in epistolam ad Philippenses 3:5/7 (CSEL 81.3:152-53) and Liber quaestionum 108 (CSEL 50:251-56). Ambrosiaster adduces the Latin example of meridie, which "sounds better" (melius sonat) than the correct form medidie (Liber quaestionum 108.5 [CSEL 50:255] and Commentarius in epistolam ad Philippenses 3:5/7 [CSEL 81.3:152]); see Souter, Study, 154.

${ }^{39}$ In Gen. 10:21 Eber is explicitly associated with Shem, ancestor of the Semites.
} 


\section{Paul and the Problem of Jewish Origins}

Once Paul has been philologically converted from a Jew to an Abrahamite, Ambrosiaster can pull on the ready-made string of Pauline citations about "true" and "spiritual" descent from Abraham meant to counter the ethnic, particularistic claims of the Jews. Abraham is the "father of faith" (Rom. 4:16; cf. Galatians 3-4), in whom the entire "human race began to be reformed." ${ }^{40}$ By claiming ties to Abraham, Paul effectively severs his ethnic connection to other Jews (in Paul's own day, and in Ambrosiaster's). Other elements that might be heard as too Jewish are likewise eliminated. As an "Abrahamite," Paul bears no connection to the Hebrew language (and thus no links with Ambrosiaster's Jewish contemporaries): Abraham was a "Chaldean," and the later "Hebrews" did not even speak his Chaldean language. So too Paul's reminder of his own circumcision-another possible link to contemporary Jews-can be explained away through Philippians 3:7, an element of the previous life now "condemned in light of Christ's promise." ${ }^{41}$

For the exegetically canny fourth-century Ambrosiaster, Paul's "archetypal Jewishness" is no Jewishness at all, and any taint of Jewish origins that might trouble the exegete has been excised. Ambrosiaster pays close attention to the problem of Jews and Judaism in his writings and evinces concern to delineate as precisely as possible the bounds of Christian-Jewish division despite-and, often, through-common Scripture and theological idiom. ${ }^{42}$ By taking hold of Paul at his most Jewish (Hebraeus ex Hebraeis) and making him speak instead in an unequivocally non-Jewish voice, Ambrosiaster maintains a thick barrier between his own Christian apostle and the Jews who (rhetorically) threaten the integrity of his faith and practice.

Like Ambrosiaster, many other fourth- and fifth-century interpreters are concerned with boundaries. What separates the Jew from the Christian, particularly in those shared spaces throughout the ancient Mediterranean where ideologically constructed boundaries were habitually

\footnotetext{
${ }^{40}$ Ambrosiaster, Commentarius in epistolam ad Philippenses 3:5/7 (CSEL 81.3:153).

${ }^{41}$ Ibid. 3:5/7 (CSEL 81.3:152).

${ }^{42}$ See, e.g., Liber quaestionum 44 (CSEL 50:71-81), ostensibly a survey of prophetic witnesses to the "new covenant," but often known as Ambrosiaster's minitreatise Adversus Iudaeos, in which the author provides a fairly rancorous narrative of Judaism's "loss" of the covenant at Mount Sinai (cf. Epistula Barnabi 4.6-7, 14.1-4 [LCL 2:22, 62-64]) and the complete erasure of their legalistic pact with God. Both the question-and-answer format of this treatise in general and the particular use of classical diatribe in this passage ("But some Jews might say . . . " [sed forte Iudaei dicant] ) create a sense (rhetorical, reflective, or both) of competitive ChristianJewish dialogue.
} 
The Journal of Religion

breached ${ }^{43}$ Unlike Ambrosiaster, however, other exegetes operated not by erasure and disavowal of Paul's Jewishness, but through appropriation and even mimicry. John Chrysostom, for example, writing in the East slightly later than Ambrosiaster, chooses to highlight Paul's Jewishness in his reading of the Philippians passage. By claiming to be a Hebrew of Hebrews, Paul "shows that he is no proselyte, but comes

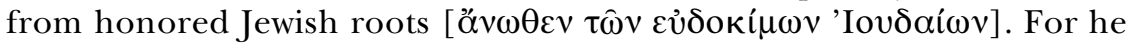
could have been of Israel, but not a 'Hebrew of Hebrews.' For many of them became corrupted in this fashion, and they began to speak in

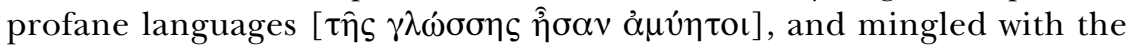
other nations. But in this respect, he shows that he is of fully noble

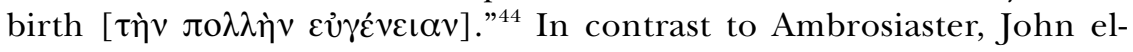
evates Paul's Jewishness to the point where no one might hope to compete-certainly, no Jew of John's day. Paul's Jewishness is "honored" and it is "noble," of a Hebrew purity that none could hope to match. Paul is, Chrysostom announces, a "Jew's Jew." By making this claim, John constructs interreligious boundaries in a surprisingly effective way: Paul's Jewishness is so superlative, he suggests, that contemporary Jews, particularly those in the Diaspora (in John's own social setting) are less Jewish than Paul. They have "mingled," become "corrupted" and "profane," and can no longer claim authentic Hebrewness. Paul, the apostle to Gentile Christians, is more Jewish than the Jews.

By focusing on Paul's Jewishness in this manner, Christians like John could then speak authoritatively about (and against) Judaism to their Christian audiences. One method of appropriating and deploying Paul's Jewish voice was to mimic and speak directly in that voice. The fifth-century Syrian bishop Theodoret of Cyrrhus, for example, produced a series of commentaries on the Pauline epistles weaving interlinear commentary, sometimes in the first-person voice, throughout the text of the letters, creating a seamless commentary-in-text in which Theodoret occasionally speaks as Paul (Paul's words are italicized): "Circumcised on the eighth day: For I didn't receive circumcision as a proselyte. Of Israel's stock. For neither was I born of proselytes, but I

\footnotetext{
${ }^{43}$ See Paula Fredriksen, "What 'Parting of the Ways'? Jews, Gentiles, and the Ancient Mediterranean City," in The Ways That Never Parted: Jews and Christians in Late Antiquity and the Early Middle Ages, ed. Adam Becker and Annette Yoshiko Reed, Texts and Studies in Ancient Judaism 95 (Tübingen: Mohr-Siebeck, 2003), 35-63.

${ }_{44}^{44}$ John Chrysostom, Homilia 10 in epistolam ad Philippenses 2 (PG 62:257-58). This particular passage was also included in the later Greek catena on Philippians. It is unclear whether John delivered the collected Philippians sermons as a priest in Antioch or after his elevation to the patriarchate in Constantinople: see Pauline Allen and Wendy Mayer, "Chrysostom and the Preaching of Hoimilies in a Series: A Re-examination of the Fifteen Homilies In Epistulam ad Philippenses (CPG 4432)," Vigiliae Christianae 49 (1995): 270-89.
} 


\section{Paul and the Problem of Jewish Origins}

can boast of Israelite origins. Benjamin's tribe: For I'm not a half-slave, but I was free-born, of the beloved Rachel, on whose behalf the patriarch indentured himself. Hebrew of Hebrews reaches back to my ancient roots. Then the rest about knowledge: by law a Pharisee, for this was the

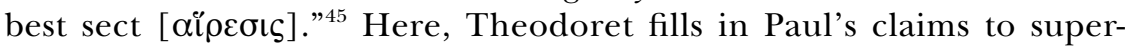
lative Jewish roots by highlighting the upwardly sliding scale of Paul's credentials: Paul neither converted, nor was he born of converts. He was not descended from Jacob's slave concubines nor from his secondchoice wife, Leah. His pedigree is pristine, all the way back to the "Hebrews." Even his sectarian choice was the "best." Theodoret's commentarial style (here, as in the rest of his commentary on Paul's letters) is simple but effective: line-by-line explication of the text to create both historical and theological context for Paul's occasional letters, making them meaningful for his fifth-century audience eager to learn how Paul "recommends to them that they flee the deceit of Jews who had been believers, trying to advocate for the Law even as they attempt to destroy utterly the salvific preaching." ${ }^{46}$

Theodoret also demonstrates a common rhetorical technique for "getting inside" the apostle and appropriating his voice: the classical trope of prosoppopoeia, or "speech-in-character," in which "a character

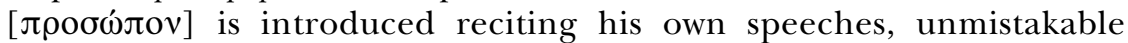
both in his person and in his underlying concerns." ${ }^{47}$ Here, Theodoret effortlessly moves between the words of Paul in Philippians and his own interpolated speech in the character of Paul, naturalizing his own exegesis. As common as prosoppopeia and related forms of oratory ventriloquism were in the canons of ancient rhetoric, speaking "as Paul" also became a persuasive tool for mediating the "true" meaning of the often elusive apostle. ${ }^{48}$ Mimicking Paul's voice in order to use his superlative Jewish credentials in the letter to the Philippians is striking: to speak as a "Hebrew of Hebrews" was to speak from the Christian

\footnotetext{
${ }^{45}$ Theodoret of Cyrrhus, Interpretatio in epistulam ad Philippenses 3.5 (PG 82:580). Theodoret moves between first-person (as here) and third-person speech throughout the commentary. For a recent translation, with some commentary, see Robert C. Hill, Theodoret of Cyrrhus: Commentary on the Letters of Saint Paul, 2 vols. (Brookline, MA: Holy Cross Orthodox Press, 2001).

${ }^{46}$ Theodoret of Cyrrhus, Interpretatio in epistulam ad Philippenses, preface (PG 82:560).

${ }^{47}$ The definition of Aelius Theon, Progymnasmata 10 (text in Rhetorici Graeci, ed. C. Hammer [Lipsius: Teubner: 1984], 2:115). See, further, Stanley K. Stowers, "Romans 7.7-25 as Speech-

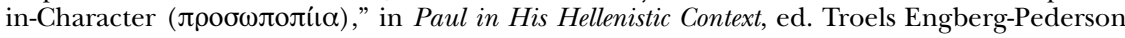
(Minneapolis: Fortress Press, 1989), 180-202, and Rereading of Romans, 264-69; and George A. Kennedy, A New History of Classical Rhetoric (Princeton, NJ: Princeton University Press, 1994), 168, 202, 206.

${ }^{48}$ See Martin ("Vox Pauli," 254-72), who explores Augustine's use of the related rhetorical trope of sermocinatio, i.e., constructing dialogues "with" Paul in his sermons (Paul's parts of the dialogues being supplied by the texts of his letters).
} 


\section{The Journal of Religion}

pulpit in the tones of an archetypal Jew. In the contest to control the boundaries of Judaism and Christianity through Paul's authoritative voice, however, speaking in that voice could be highly effective.

We can witness this quite clearly in the sermons of John Chrysostom, whom we have already seen elevating Paul's Jewishness to the point where not even John's Jewish contemporaries might hope to compete. The use to which John can put this superlative Jewishness becomes

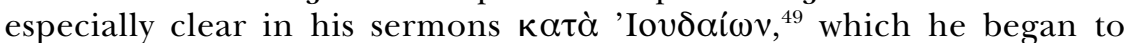
deliver in Antioch in autumn 386 CE. ${ }^{50}$ John interrupted the beginning of a series of sermons against Arians in order to fulminate against members of his own community who frequented the local synagogues: participating in Jewish fasts, swearing oaths on the Torah scrolls, and generally admiring the sanctity and piety of Judaism to the point that John's blood seems to boil. ${ }^{51}$ The central goal of these homilies is clear: to reinstate (or, perhaps, construct entirely) a decisive theological and ritual boundary between Christians and Jews. ${ }^{52}$ In this context, Paul's multiple voices helpfully articulate a figure who could speak as "a Jew and a Christian," 53 yet at times remain paradoxically "foreign to Judaism" ${ }^{, 54}$ and "a Hebrew of Hebrews." ${ }^{55}$ Paul is, for John, the archetypal Jew and archetypal Christian apostle at once, and so John can "make

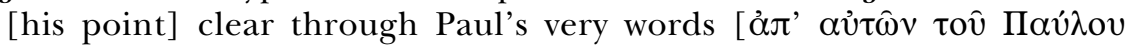

${ }^{49}$ This is the title (usually translated adversus Iudaeos or "Against the Jews") found in the collection of manuscripts. Although it is often pointed out that John is actually preaching against Judaizers-i.e., gentile Christians who insist on affiliating with Jewish rituals or sacred spaces-there is doubtless enough invective against non-Christian Jews to let the more abbreviated title stand in for the sake of convenience.

${ }^{50}$ Robert L. Wilken (John Chrysostom and the Jews: Rhetoric and Reality in the Late 4th Century, Transformation of the Classical Heritage 4 [Berkeley: University of California Press, 1983], 34-35 and 67) suggests that John was prompted by the approaching High Holy Days (Rosh Hashanah and Yom Kippur). The sermons were not delivered all at once: Wilken (John Chrysostom, 67-68 n. 3) places all of the sermons around the Jewish High Holidays in autumn 386 and 387 , with the exception of the third homily, in late winter/early spring 387 (before Lent).

${ }^{51}$ Wilken (John Chrysostom, 116-27) attempts to demonstrate that John's often shockingly abusive rhetoric in these sermons draws to a great extent on classical rhetorical tropes of psogos, or invective; more generally, see Mitchell, Heavenly Trumpet, 22-28.

${ }^{52}$ John's treatment of the "Judaizing" of his congregation as a horrifying innovation must be placed in the context of heresiological tradition in which all "heresy" is deviation from a more original truth. We simply cannot know the extent to which boundary crossing and interreligious participation was common or unremarkable in fourth-century Antioch or the late ancient world in general: see now Daniel Boyarin, Border Lines: The Partition of JudaeoChristianity, Divinations (Philadelphia: University of Pennsylvania Press, 2004).

${ }^{53}$ John Chrysostom (Homilia 41 in Actos Apostolorum 1 [PG 60:326]), commenting on Acts

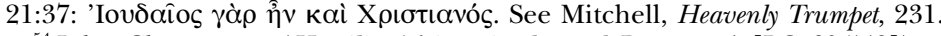

${ }^{54}$ John Chrysostom (Homilia 16 in epistulam ad Romanos 1 [PG 60:549]), commenting on

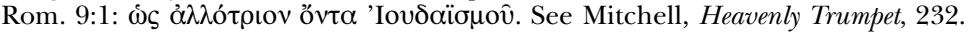

${ }^{55}$ Mitchell (Heavenly Trumpet, 228-34), notes the range of John's opinions on Paul's "Jewishness." 


\section{Paul and the Problem of Jewish Origins}

$\eta \mu \alpha \dot{\tau} \tau \omega v] . "{ }^{56}$ Just as Paul can "out-Jew" the Philippian Judaizers, so too John, by speaking in Paul's voice, can "out-Jew" their Antiochene successors.

John creates a parallel between Paul and himself and between his audience and Paul's: "For what Paul said the Galatians, so now I too say to you: 'Become like me, because I also have become like you' (Gal. $4: 12)$." For John, the goal of this imitation is clear: "He was persuading them to renounce circumcision, to disdain sabbaths and [feast] days, and all the other legal observances. ${ }^{157}$ Paul had given up these Jewish practices; so too must the Galatians. So must the Judaizing Antiochenes in John's congregation imitate Paul (by giving up their Jewish customs) and imitate John (by becoming faithful, orthodox Christians). To drive his point home, John draws himself even closer to Paul, lapsing into a Pauline prosōpopoeia designed to highlight Paul's (and John's) criteria for authority: "For did I come from the Gentiles? he says. Was I inex-

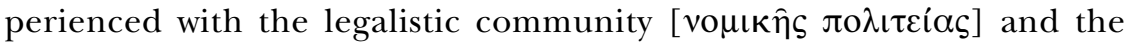
punishments determined for those who transgress the Law? A Hebrew of Hebrews, according to the Law a Pharisee, according to zeal a persecutor of the church. But even those things which were a gain to me, I counted as a loss because of Christ: that is, I stood apart from them entirely. So become like me, for I was once just like you!" ${ }^{58}$ Paulchanneled through John-can speak about the failures of the law because he excelled in it: the closing refrain, a moderated form of Galatians' call to imitation that John had already made his own, ensures that Paul's and John's voices becomes intertwined.$^{59}$ For that moment, John himself can speak as a "Jew's Jew" in order to lure his Christian flock away from the Jewish "wolves" trying to rip them apart. ${ }^{60}$

Sometimes a shepherd, sometimes a hunter, John uses Paul's voice like a lure to force the Judaizers into the open: "For when many wild, savaging animals, hiding under the shrub, happen to hear the sound of the hunter, they leap up from fear. . . . So too your brothers, hiding in another 'shrub'-Judaism-might hear Paul's voice, and I know well that they will fall quite easily into the nets of salvation and reject all Jewish error." ${ }^{11}$ We should keep in mind the dramatic and performative

\footnotetext{
${ }_{57}^{56}$ John Chrysostom, Adversus Iudaeos 3.2.2 (PG 48:863).

${ }^{57}$ Ibid. 3.3.1 (PG 48:864).

${ }^{58}$ Ibid. 3.3.2 (PG 48:864-65).

${ }^{59}$ Mitchell's excellent study, Heavenly Trumpet, outlines in sympathetic and exhaustive detail the rhetorical and psychological intertwining at work in John's writings on Paul: "John's singleminded concentration on Paul was due to the fact that he had a special love for him" (68).

${ }^{60}$ A repetitive image of reciprocal violence running through these homilies: Adversus Iudaeos 3.1.1, 3.7.8, 4.1.1-2 (PG 48:861, 863, 871).

${ }^{61}$ Ibid. 2.1.5 (PG 48:857-58).
} 


\section{The Journal of Religion}

effect of the Christian bishop using the voice of the "Jew's Jew" to draw these wandering Christian sheep back into the fold. It is instructive to imagine John before his Antiochene congregation (in an era before "finger quotes") so effectively speaking in Paul's Jewish voice:

For what reason did Paul place his own name here [in Gal. 5:2: "I, Paul, say to you ..." "], instead of simply saying, "I say to you"? Because he wishes to call it to their minds, Paul demonstrates his zeal for Judaism. So he says, "If I were from the Gentiles, and didn't know about Jewish matters, someone might plausibly argue that I don't understand the effectiveness of circumcision because I have not partaken of the rites of this community [ло $\lambda \iota \tau \varepsilon i \alpha \varsigma$ ], and that's why I reject it from the church's teachings." So he [Paul] establishes his name, as a reminder of the struggle he undertook for the law, saying all but: "I do this not out of enmity for circumcision, but in true knowledge of it [ $\dot{\varepsilon} v$

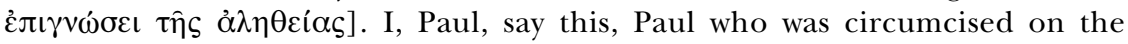
eighth day, of Israelite birth, a Hebrew of Hebrews!" 62

Here John can speak like Paul, as Paul, as a simultaneous insider and refuter of Judaism: like Paul, John's credentials for gainsaying Judaism are now above reproach-indeed, beyond those of the Antiochene Jews who are luring away his parishioners. There is a sense of clever mimicry, like the hunter's call: Christians drawn to the synagogue by the allure of Judaism will be drawn back to the church by the same call, only louder and more authentic. By slipping into Paul's Jewishness, John can defeat Judaism's perilous appeal from the inside out. ${ }^{63}$

While John speaks in Paul's voice in order to chastise Judaizing Christians, fifth-century Alexandrian bishop Cyril employs Paul's Jewish voice directly against the Jews of his own time and place. Better known for his role in the rancorous Christological controversies of the first half of the fifth century, Cyril was also a prolific homilist and exegete, engaged with equal ferocity in Alexandrian quarrels with heretics, "pagans," and Jews. ${ }^{64}$ Like his predecessors in the see of Alexandria, Cyril took the occasion of the announcement of the date of Easter to address ecclesiastical controversies and to "remind" his flock

\footnotetext{
${ }^{62}$ Ibid. 2.2.2 (PG 48:858-59).

${ }^{63}$ So Mitchell (Heavenly Trumpet, 233 n. 147): "Chrysostom understands Paul as the oratorical adversary of Jews and Judaizers par excellence, whose person and voice he seeks to emulate."

${ }^{64}$ See the recent biographical overview of Normal Russell, Cyril of Alexandria, The Early Church Fathers (London: Routledge, 2000), 1-63. Robert L. Wilken (Judaism and the Early Christian Mind: A Study of Cyril of Alexandria's Exegesis and Theology [New Haven, CT: Yale University Press, 1971]) places Cyril's Christology squarely in an exegetical and social context in late ancient Alexandria; see now his "Cyril of Alexandria as Interpreter of the Old Testament," in The Theology of St. Cyril of Alexandria: A Critical Appreciation, ed. Thomas G. Weinandy and Daniel A. Keating (London: Clark, 2003), 1-21.
} 


\section{Paul and the Problem of Jewish Origins}

of the appropriate religious boundaries of their Christianity. ${ }^{65}$ Because the dating of Easter in the ancient world was so contested-and so mixed-up with the confusion over Jewish origins and Jewish-Christian boundaries-we should not be surprised to find some of Cyril's most vicious anti-Jewish rhetoric in these letters. And, since Paul provided such a reliable source of authority from which to speak within/against Judaism, we should not be surprised to find the apostle's voice channeled through the bishop.

In the Paschal letter setting the date for Easter in 418, Cyril addresses himself directly to three distinct audiences: newly baptized Christians, whom he exhorts to enjoin the battle of spirit against flesh; "pagans" ("E $\lambda \lambda \eta \dot{v} \nu \omega \nu \pi \alpha \hat{\delta} \delta \varepsilon \varsigma$ ), for whom he demonstrates the absurdity of Greek mythology and idolatry; and Jews, against whom he lashes out because they are so "mired in the forms of the [scriptural] letter," unable to "move beyond to the power of the truth." ${ }^{66}$ Most of Cyril's pastoral energies in this letter, in fact, are reserved for the Jews: for half the text he berates them for remaining stubbornly ignorant of the emptiness of the "letter" of the law. Cyril focuses particularly on their misunderstanding of circumcision and the Sabbath, drawing proofs from both Old and New Testaments as well as the witness of the natural world ${ }^{67}$ The final and most persuasive witness, however, is the apostle Paul, precisely for his superlative Jewishness. At the climax of Cyril's discussion of the "real," spiritual Sabbath (as opposed to the leaden and unspiritual Sabbath of the Jews), Cyril brings Paul forward:

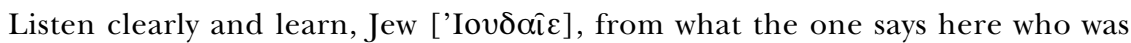
"educated at the feet of Gamaliel" (Acts 22:3), the one who has total knowledge of the law, a "Hebrew of Hebrews, of Benjamin's tribe, a Pharisee ac-

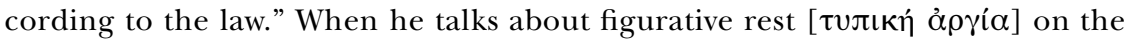
Sabbath, introduced through the letter of the law, he says that there is nothing

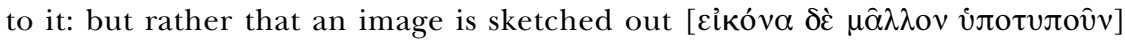
of the good things hoped for, and of the rest that will be given to the saints at that time, when the Savior of all comes down from heaven in the glory of his Father. ${ }^{68}$

\footnotetext{
${ }^{65}$ On the nature and functions of these so-called Festal Letters, see the thorough introduction of Pierre Évieux, Cyrille d'Alexandrie: Lettres Festales I-VI, Sources chrétiennes 372 (Paris: Cerf, 1991), 73-118; and John A. McGuckin, "Cyril of Alexandria: Bishop and Pastor," in Weinandy and Keating, Theology of St. Cyril, 205-36, at 222-27.

${ }^{66}$ Cyril of Alexandria, Epistula paschale 6.6 (SC 372:364). Wilken (Judaism, 24) notes the frequency of this classical tripartite apologetic structure-defining Christianity over again "Hellenism" and Judaism-in Cyril's writings, particularly the Paschal letters.

${ }^{67}$ Cyril of Alexandria (Epistula paschale 6.10 [SC 372:380]) points out that "all the rest of creation operates without hindrance according to its natural movements on the Sabbath."

${ }^{68}$ Ibid. 6.11 (SC 372:390-92).
} 


\section{The Journal of Religion}

Paul is not even explicitly named here, but merely indicated by his Jewish credentials, including a citation of Philippians 3:5-6. All that is necessary for the bishop to score his point here is Paul's Judaism, complete and knowledgeable, juxtaposed to the ignorance of the straw-Jew Cyril has invoked to address. Cyril forces a confrontation between Paul the Jew-who understands the typological nature of "circumcision" and "Sabbath" - and "the Jew" who is the object of Cyril's dismissive exegetical and rhetorical rancor. Paul clearly wins the day: Cyril states, "Well, that's enough of that," ${ }^{69}$ and moves on to a summary of salvation history and the date for that year's Easter commemoration.

In another Paschal letter, Cyril also engages in the kind of prosōpopoeia we saw in Theodoret and John Chrysostom. Strikingly, Cyril does not speak only in the voice of the Jewish Paul but also in the voice of his straw-Jew who protests against Paul. In the Paschal letter setting the date for Easter of 416, Cyril cites Paul (actually, the letter to the Hebrews) in order to demonstrate the lapsed covenant of the Jews and the meaninglessness of the Jewish Passover. ${ }^{70}$ Cyril then launches into a direct, second-person attack on "the Jew":

How long will you remain unconvinced, Jew? At what point will you agree with the voices of the saints? But perhaps [you'll say]: "That's your Paul, not mine,

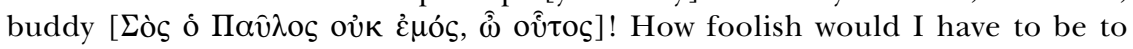

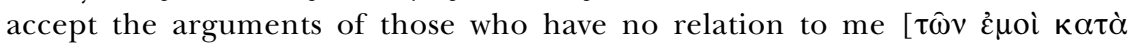

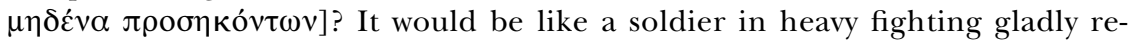
ceiving the blows of his enemies!" Finely and justly said; but really you deny

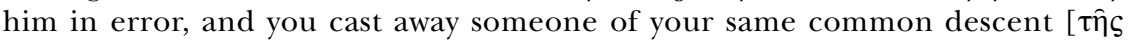

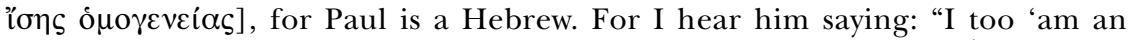
Israelite, a Hebrew of Hebrews, a Pharisee according to the Law!',71

Cyril first speaks in his own voice (directly addressing "the Jew"); then

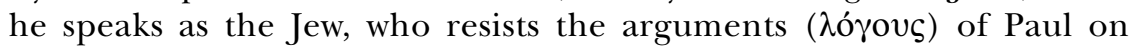
the grounds that Paul is not Jewish, but rather the enemy (Christian, presumably). Then Cyril both "hears" and speaks the voice of Paul: by

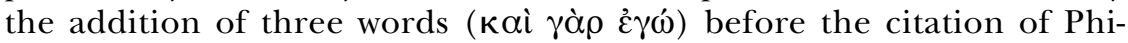
lippians 3:5, Paul's words become Cyril's. In this one passage, Cyril ventriloquizes two Jewish voices: the voice of resistant disbelief and the voice of apostolic surety. The notion that the Christian bishop might

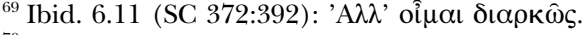

${ }^{70}$ The relation between the Jewish Passover and Christian Easter was both a theological and practical concern well into the fifth century, as Christians continued to calculate the date for Easter according to the Jewish luni-solar calendar, the "heresy" of the so-called quarto-

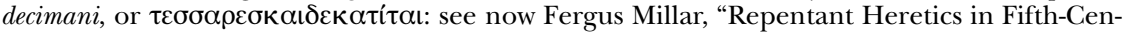
tury Lydia: Identity and Literacy," Scripta Classica Israelica 23 (2004): 111-30.

${ }^{71}$ Cyril, Epistula paschale 4.6 (SC 372:264).
} 


\section{Paul and the Problem of Jewish Origins}

so accurately mimic the voice of the Jew is a devastating rhetorical tour de force, enabled by the paradigmatic Jewishness of the Christian apostle Paul. Yet at the root of this rhetorical confidence is a lurking fear: that this originary Jewishness might call religious boundaries into question and might actually create a border-zone where "Jew" and "Christian" overlapped.

Ambrosiaster, John, and Cyril all attest to this anxiety over Jewish origins, demanding concerted attention to Paul's refutation of Jewish custom and "law." Yet they do not turn solely to Paul's more polemic rejection of "the law" (although they certainly have occasion to do this, as well). They also draw on Paul at his most Jewish, to "out-Jew" the Jewish threat, to speak in the most authentic Jewish voice and so undo Judaism from within. Only Ambrosiaster tries to make Paul's Judaism into something entirely different; for Cyril and John, speaking in Paul's own Jewish voice, making of themselves "Hebrews of Hebrews," affords them the occasion to rhetorically subject all Jews and Judaism to Christian authority. Paul's boasting in Philippians 3 allows Christians to disarm the enticing Jewishness at the root of Christianity: all the Judaism a good Christian needs can be found in the mouth of the apostle.

THROWING PAUL'S JEWISH VOICE

At times Christians in this late ancient century of Paul transferred this epithet, "Hebrew of Hebrews," to other prominent Jewish figures, who could then be used to equal effect in the struggle to acknowledge and defuse Christianity's alluring originary Jewishness. Cyril of

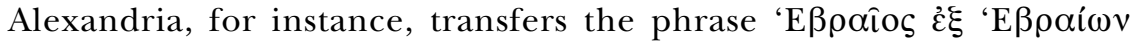
in one of his earliest exegetical works, the Glaphyra (or "Polished Comments"), a commentary on the Pentateuch. ${ }^{72}$ After laying out a basic typological and allegorical interpretation of the circumstances of Moses's birth in Exodus 2:1-10, in which the narrative details of the story correspond directly to theological and historical truths about Christ and the church, ${ }^{73}$ Cyril draws a parallel between young

\footnotetext{
${ }^{72}$ As Russell (Cyril, 10) points out, dating of Cyril's works before the outbreak of his controversy with Nestorius is less certain, but the Glaphyra is certainly among his earliest exegetical efforts, probably accomplished after his earlier commentary on the Pentateuch, the Adoration in Spirit and Truth: see Wilken, Judaism, 84, following G. Jouassard, "L'activité littéraire de Saint Cyrille d'Alexandrie jusqu'à 428: Essai de chronologie et de synthèse," in Mélanges E. Podechard (Lyon: Facultés Catholiques, 1945), 160-74.

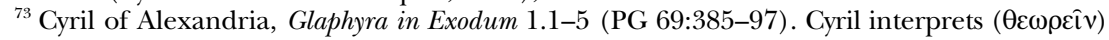
both typologically (Pharaoh's daughter $=$ the church from the gentiles, Moses's mother $=$ the synagogue of the Jews) and morally $($ Pharaoh $=$ Satan $/$ sin, "male children" = virtues and courage).
} 


\section{The Journal of Religion}

Moses fleeing from Egypt into the desert of Midian and Christ being born among the Jews:

You might rightly be amazed at this: that he [Christ] of necessity came down from above into the land of Judah, among those by whom he was mocked impiously; there he was born according to the flesh. But, in truth, he wasn't a Jew, insofar as he was the Word, but rather from both heaven and his father. Just as, of course, divinely sweet Moses was born in Egypt, and he was a Hebrew of Hebrews, having a noble stock and his father's holiness. ${ }^{74}$ But when those of his own blood reproached him, and finally the two of them turned his actions into accusations, ${ }^{75}$ he went out into Midian, and settled down in the country of foreigners $[\dot{\varepsilon} \tau \varepsilon \rho o \gamma \varepsilon v \hat{\omega} v] .{ }^{76}$

Just as Moses was driven from the land of sin (Egypt) by his bloodrelatives (Hebrew slaves), so too Christ removed himself from his sinful kin according to the flesh (the Jews) to save the gentiles. The ironic rejection and reversal are highlighted by making Moses a superlative

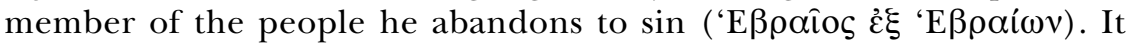
is possible that Cyril is reminded of the epithet "Hebrew of Hebrews" by the repetition of the term "Hebrew" in these passages from Exodus. ${ }^{77}$ Nonetheless, he is also subtly drawing on the superlative Jewishness of Paul, projecting it back onto Moses-the giver of the law, of a priestly family-in order to create a constructive parallel with the problematic originary Jewishness of Jesus himself. Just as Paul's Jewishness serves to construct true Christianity, so too Moses, and Jesus himself, enjoy the double-voiced assurances of a Judaism that ultimately deconstructs itself.

Other figures from the distant Jewish past might be reconfigured by fourth- and fifth-century interpreters in Paul's likeness as "Hebrews of Hebrews." Eusebius of Caesarea, for instance, famously attempted to construct a sacred history that explained the relationship of Christianity to its Jewish origins. This project, articulated in Eusebius's early fourth-century treatise the Praeparatio evangelica, entailed a bifurcation of Jewish history. The "Hebrews" of the past, Eusebius argued, were the pure, monotheistic people of God who shared in the faith of Abraham before the time of Moses. By contrast, the "Jews" were those less spiritual, fleshly descendants of the "Hebrews" who could not keep God's faith without the stern taskmaster of the law, provided for them

\footnotetext{
${ }^{74}$ That is, his father was of the priestly tribe of Levi: Cyril is making a typological connection with the Father and the Holy Spirit.

${ }^{75}$ That is, the two "Hebrews" who mock Moses for killing the Egyptian taskmaster, prompting Moses's flight in Exod. 2:13.

${ }^{76}$ Cyril of Alexandria, Glaphyra in Exodum 1.7 (PG 69:404-5).

${ }^{77}$ Exod. 1:22, 2:11, 2:13.
} 


\section{Paul and the Problem of Jewish Origins}

by Moses. ${ }^{78}$ According to Eusebius, then, Christians could reconstruct their originary Jewishness as "Hebrewness," and thus avoid theological contamination by present-day Jews.

The Philippians epithet and its superlative Hebrewness neatly assisted Eusebius in this historiographic project. Heroic figures from the "Jewish" past could be recuperated as "Hebrews"; the truly excellent Old Testament heroes could suitably be assigned Paul's epithet. For instance, Eusebius marvels at the "virtuous judgment" ( $\sigma \omega ́ \phi \rho o v \iota ~ \lambda o \gamma \iota \sigma \mu \hat{)})$ of Jacob's son Joseph that brought him to power over his Egyptian "masters," and proclaims: "Now surely, [Joseph] was a Hebrew of Hebrews, and not a Jew; because there weren't any 'Jews' yet among these exceedingly God-beloved and thrice-blessed people." ${ }^{79}$ Here the triumph of the downtrodden yet chaste ( $\sigma \omega \phi \rho o \varsigma)$ servant of God over his impious "masters" serves as an exemplar to fourth-century Christians (themselves coming to power over impious masters); these Christians remain spiritual descendents of the "Hebrews" without fear of making a Jew into a figure for religious emulation. ${ }^{80}$

Moses also emerges as a superlative Hebrew in Eusebius's account, even at the very moment at which "the Jews" come into existence: "Now the great theologian Moses, who was a Hebrew of Hebrews, understood as well as anyone could his native customs [ $\tau \grave{\alpha} \pi \alpha \dot{\tau} \tau \rho \iota \alpha]$. So as a preface to his sacred laws he set forth the lives of the Hebrew patriarchs, in indelible memorials; some of these were deemed worthy before God, while others, for their manner and comportment, were deemed godless and impious. He thought it necessary to keep this teaching (to flee from sympathy for the baser ones and to preserve the manner of life of the pious ones) in order to teach the law to those who could come later." " "Those who would come later" are, simply put, the Jews, for whom Moses is constructing an edifying (although constraining and as yet imperfect) law, consisting of both ordinances and narratives with moral content. For Eusebius, the law is the line that divides the Hebrews (whose spiritual descendants will be the Christians) from the

\footnotetext{
${ }^{78}$ This historiographic innovation is laid out in Eusebius, Praeparatio evangelica 7.6 (SC 215: 168-70). See Jörg Ulrich, Euseb von Caesarea und die Juden: Studien zur Rolle der Juden in der Theologie des Eusebius von Caesarea, Patristische Texte und Studien 49 (Berlin: de Gruyter, 1999), esp. 57-131; Andrew S. Jacobs, Remains of the Jews: The Holy Land and Christian Empire in Late Antiquity, Divinations (Stanford, CA: Stanford University Press, 2004), 29-32; and Aaron P. Johnson, "Ancestors as Icons: The Lives of Hebrew Saints in Eusebius' Praeparatio Evangelica," Greek, Roman, and Byzantine Studies 44 (2004): 245-64, 262-63.

${ }^{79}$ Eusebius, Praeparatio evangelica 7.8.36 (SC 215:196).

${ }^{80}$ On the appeal of Joseph, particularly as a figure of chastity, among early Christians, see Ross Shepard Kraemer, When Aseneth Met Joseph: A Late Antique Tale of the Biblical Patriarch and His Egyptian Wife, Reconsidered (New York: Oxford University Press, 1998), 245-85.

${ }^{81}$ Eusebius, Praeparatio evangelica 7.7.1 (SC 215:172).
} 
The Journal of Religion

Jews. To inscribe Moses as a "Hebrew of Hebrews" at this moment therefore reaffirms the crucial distinction between Christian/Hebrew and Jew, while preserving the carefully constructed continuity of Eusebius's sacred history. Both Joseph's and Moses's exceeding piety (registered as exceeding "Hebrewness") echoes and prefigures the piety of the apostle to the gentiles by the appropriation of this epithet. In turn, Paul's own piety now drifts back historically into the time of the "Hebrews": the Jewishness of Paul and that of Moses are now rendered more palatable to Christian readers, and the threat of Jewish origins has been doubly contained.

Eusebius's tidy historical distinction at times becomes blurred as he finds figures well beyond the Mosaic watershed whose religious significance must nonetheless be recuperated in his historical theology. A rash of figures, from King David to the prophets to the Maccabees and the translators of the Septuagint, are given the label "Hebrew," as well as post-Biblical figures, such as the Alexandrian philosopher Philo and even Trypho, the (perhaps literarily constructed) Jew with whom the second-century Christian philosopher Justin Martyr debated.$^{82}$ Despite various scholarly attempts to explain this terminological confusion, these figures-both saintly and reprehensible, in Eusebius's eyesshare little in common apart from their usefulness is articulating the amorphous boundaries of Christian identity.

The superlative epithet of Paul could be used to blur these boundaries, as well. On one occasion, Eusebius is making a historical argument about the coming of Jesus as predicted in the prophets. He cites Zechariah 14:5, which reads: "And the valley of my mountains will be closed up, and the cleft of the mountains will be joined to Asael, and it will be closed up as it was closed up in the time of the earthquake in the days of Uzziah, King of Judah." ${ }^{83}$ Eusebius (naturally) assumes that the "closing of the valley of the mountains" refers to the consummation of the law of the Jews, accomplished when Jesus ascended from the Mount of Olives (Asael, in the Septuagint). ${ }^{84}$ But Eusebius cannot

${ }^{82}$ See the references of Ulrich, Euseb, 64-67. Timothy J. Horner (Listening to Trypho: Justin's "Dialogue with Trypho" Reconsidered, Contributions to Biblical Exegesis and Theology 28 [Leuven: Peeters, 2001]) has recently argued for the veracity of Trypho as depicted in the Dialogue; but see also Tessa Rajak, "Talking at Trypho: Christian Apologetic as Anti-Judaism in Justin's Dialogue with Trypho the Jew," in her The Jewish Dialogue with Greece and Rome: Studies in Cultural and Social Interaction, Arbeiten zur Geschichte des antiken Judentums und des Christentums 48 (Leiden: Brill, 2001), 511-33.

${ }^{83}$ Eusebius, Demonstration evangelica 6.18.2 (GCS 23:279).

${ }^{84}$ The Septuagint renders the enigmatic Hebrew of this passage, אצל (probably "alongside"),

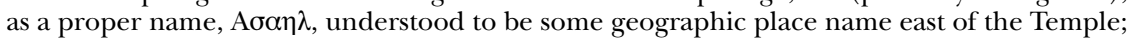
Christians, reading Zechariah through the lens of the New Testament, understood this to be 


\section{Paul and the Problem of Jewish Origins}

find mention of an earthquake in the time of Uzziah in the Bible, and instead turns to a different "Hebrew" source: "It is told how Uzziah in the beginning was just, then he went mad and dared to sacrifice on his own behalf to God. So he became leprous in his face. All this is recounted in the book of Kings ${ }^{85}$ But Josephus, who was especially

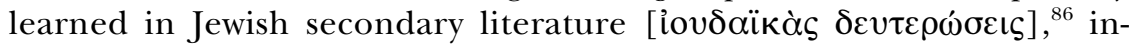

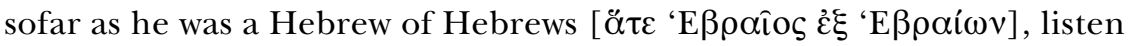
to how he lays out what happened in those times. . . ." then cites a passage from Josephus's Antiquities of the Jews ('Iоvઠаїкทิৎ

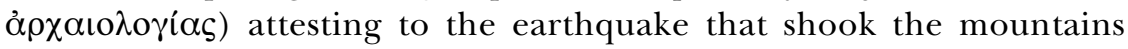
at Uzziah's impiety. For his utility in affirming the Christological events of an ancient king of Judah, Josephus is granted status as a superlative "Hebrew," even as he somewhat paradoxically cites "Jewish literature," indeed, a text bearing the name of "the Jews." I do not think it is a question here that Josephus is a crypto-Christian of some sort; Eusebius refers to him as a "Jew" as well as a "Hebrew" (or even, as here, "Hebrew of Hebrews"). ${ }^{88}$ Rather, like Paul (and through this subtle identification with Paul), Josephus speaks with a double voice: a witness to authentic Judaism, as the historian of the Jews, and a witness to "Hebrewness," in those moments where his Jewish voice supplies crucial testimony to the validity of Christ and Christianity.

The Jewish origins of Christianity created a historical and theological imprecision for Eusebius, as for other Christians, despite claims to terminological exactitude. Eusebius can therefore refer to John the evangelist as a "Hebrew of Hebrews," not only for his theological purity as a true monotheist (like the ancient Hebrews) but also for his ethnic Jewishness. In his Gospel Preparation, Eusebius cites a Middle Platonist philosopher named Amelius, a student of Plotinus. ${ }^{89}$ Amelius refers to a (nameless) philosopher among the "barbarians," who had written

Mount Olivet: see the discussion of this transliteration/translation in Jerome, Commentarius in Zachariam 3.14.5 (CCL 76A:880-81).

${ }^{85}$ The account of Uzziah's leprosy is told most fully in 2 Chron. 26; the parallel account, in 2 Kings 15:1-5, calls the king Azariah; in both accounts, the king suffers leprosy after he usurps the priestly privilege of sacrificing on the Temple altar.

${ }^{86}$ My translation here of $\delta \varepsilon v \tau \varepsilon \rho \omega ́ \sigma \varepsilon เ \varsigma$ as "secondary literature" (the term is certainly a Greek translation of the Hebrew mishnah, or "repetition") is meant to emphasize Christian mistrust of this literature as secondary to and derivative of the primary source, the Bible.

${ }^{87}$ Eusebius, Demonstratio evangelica 6.18.36 (GCS 23:281).

${ }^{88}$ See Ulrich, Euseb, 100-110.

${ }^{89}$ Eusebius is our only source for this Platonist reference to the Gospel of John: see Paul Kalligas, "Traces of Longinus' Library in Eusebius' Praeparatio Evangelica," Classical Quarterly 51 (2001): 584-98. The Praeparatio evangelica is an astounding pastiche of Greek philosophical and literary texts, many of which would otherwise be lost: see recent discussion in Aaron P. Johnson, "Identity, Descent, and Polemic: Ethnic Argumentation in Eusebius' Praeparatio Evangelica," Journal of Early Christian Studies 12 (2004): 23-56, esp. 23-24. 
The Journal of Religion

that God's "Word" is eternal, and that it was "with God, and it was God, and everything simply came to exist through it." Eusebius annotates: "Whose else was this 'barbarian' of whom he speaks, if not the evangelist of our savior, John, who was a Hebrew of Hebrews?" ${ }^{90}$ Like the "Hebrewness" of Josephus (and, again, subtextually like that of Paul), John's status as a "Hebrew of Hebrews" speaks with two voices. On the one hand, he speaks in the voice of monotheistic purity, connecting the sacred histories of the Scriptures with the theological fulfillment of Christianity. On the other hand, he speaks with the voice of Jewish authenticity, the "barbarian" (i.e., Jew, and non-Hellene) articulating the cultural boundaries of Hellenism (paganism) and monotheism in Eusebius's apologetic scheme. By throwing Paul's most Jewish voice onto the evangelist, Eusebius can pull forward his historical anchor of "Hebrew" identity into the time of Jesus and deploy it even against third-century Greek philosophers.

Later in the fourth century, and into the fifth century, we find the scriptural expert Jerome also casting Paul's doubled Jewish voice about in an attempt to delineate Jewish-Christian boundaries precisely at their most nebulous junctures. While for Eusebius "Hebrewness" ultimately indicated a theological position of "Ur-monotheism," ${ }^{91}$ Jerome more often constructs Hebrewness as a display of linguistic and cultural expertise. Jerome's "Hebrews of Hebrews" populate the time of Jesus himself, the very moment at which originary Jewishness morphs into something else: Christianity. In addition to being an eager controversialist and sought-after ascetic maestro, Jerome was most famous in the ancient world for his rigorous biblical expertise. Returning (not without uproar, as his correspondence with Augustine suggests) to the original Hebrew language of the Bible, Jerome promised his readers a more authentic and more true-that is, more Christian-biblical text. That the Hebraica veritas, the "Hebrew truth" of the Old Testament, should lead to a more inspired and authentic Christian message, indicates from the outset the strategy by which Jerome sought to exploit the original Jewishness of his Christianity.

The appropriation of original Jewishness as a tool for constructing truer Christianity emerges, for instance, at moments of intertestamental uncertainty in the text of the Gospels. Jerome takes the example of the evangelist John, who cites Zechariah 12:10 in his account of Christ's passion (at John 19:37): "And another scripture says: They shall look upon him whom they pierced (confixerunt)." Unfortunately,

\footnotetext{
${ }^{90}$ Eusebius, Praeparatio evangelica 11.19.1-2 (SC 292:146-48).
}

${ }^{91}$ Ulrich, Euseb, 59-68. 


\section{Paul and the Problem of Jewish Origins}

such a passage is not found in the Septuagint, but rather it reads "They shall look upon him whom they ridiculed (insultaverunt)." Jerome explains that it is a matter of similar Hebrew letters being confused. The Seventy Translators confused the resh with the daleth, because they were more familiar with Greek than with Hebrew. ${ }^{92}$ This is not the case for John: "Now John the evangelist, who drank his wisdom from the Lord's breast, a Hebrew of Hebrews whom the Lord loved greatly, was not especially concerned with Greek literary composition. Rather, he translated word for word what he read in the Hebrew, and said that it had been fulfilled at the time of the Lord's passion." ${ }^{93}$ John, conveying Hebraica veritas to a Greek-speaking audience through his Gospel, translates the original prophetic words of Zechariah more accurately than the Seventy. ${ }^{94}$ Christian prophecy is therefore more accurately communicated thanks to John's superlative Jewishness, his status as a "Hebrew of Hebrews." John's expertly Jewish voice more accurately leads to Christian truth: like Paul's, it is the doubled voice of Jewish expertise and Christian piety.

Yet as we see more examples of Jerome's deployment of Paul's "Hebrew of Hebrews" epithet, it becomes clear that this evangelical Jewishness is not quite what it seems. The superlative Jewishness of the apostles and evangelists suggests not a rigid adherence to Hebrew language and culture but rather a creative form of expertise to be modulated and manipulated at will. In another instance in which Jerome must explain the unusual biblical citation practices of the evangelists,${ }^{95}$ Jerome writes: "It would seem that the evangelist Matthew, not bound by the old translation, could set aside the Hebrew truth; but as a Hebrew of Hebrews, most learned in the Lord's Law, he offered forth for

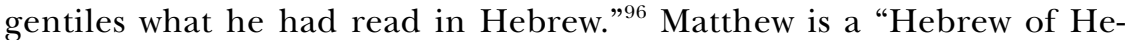
brews," so expert in Judaism that he possesses even the linguistic and cultural expertise necessary to convey, as helpfully as possible, the Jewish prophecies to a gentile audience. In fact, his excellent Hebrewness even allows him, at times, to disregard (and, it is suggested, surpass) the Hebraica veritas of the Old Testament itself.

Jews might be bound up in the "letter" of the law, but the skill of the "Hebrew" apostles allows them to exceed this restrictive Jewish

\footnotetext{
${ }^{92}$ That is, the Seventy saw רקדו (leap about, [in]saltare) instead of דקרו (pierce).

${ }^{93}$ Jerome, Commentarius in Zachariam 3.12.10 (CCL 76A:868).

${ }^{94}$ On Jerome's attitude toward (the multiple editions of) the Septuagint, see Adam Kamesar, Jerome, Greek Scholarship, and the Hebrew Bible: A Study of the "Quaestiones Hebraicae in Genesim," Oxford Classical Monographs (Oxford: Clarendon, 1993), 41-72.

${ }^{95}$ Here it is Matt. 12:20: "He will not break a bruised reed or quench a smoldering wick," a somewhat free rendering of Isa. 42:3.

${ }^{96}$ Jerome, ep. 121.2.5 (CSEL 56:9).
} 


\section{The Journal of Religion}

boundary in the preaching of Christian truth. Speaking of the evangelists and apostles as a group, Jerome exclaims that they all enjoyed this linguistic freedom and "did not always follow the Hebrew version; rather, as Hebrews of Hebrews, because they could read Hebrew, they expressed themselves in their own words. ${ }^{\text {"97 }}$ Here we begin to see the payoff for Jerome's extension of Paul's double-voiced, superlative "Hebrewness." Now it is not just the later Christian interpreter but the authors of Christian Scripture themselves who have become the ventriloquists, miming "Jewishness" with an expertise surpassing other Jewish readers of the Bible. Their "Hebrewness" does not express some ontological religious identity, but rather proficiency, training, and art. For this reason, here, they are described as quasi Hebraei ex Hebraeis: "as" or even "as if they were Hebrews of Hebrews."

Jerome is thus able to splinter off Hebrewness as a religious identity, the haunting Jewishness of Christian origins, from "Hebrewness," which has become for Jerome a rhetorically expedient posture. Paul is also among these Hebrew ventriloquists, speaking "quasi Hebraeus ex Hebraeis." Jerome explains how cleverly Paul adapted and "paraphrased" scriptural witness, "like a Jew's Jew," when he wrote to the Corinthians, "not rendering word for word . . . but expressing the true sense." ${ }^{99}$ This admiration for Paul's skills in Jewish mimicry begins to shade into Jerome's own project at appropriating the "Hebrew" voice of Scriptures to convey a truer and more authentic Christianity. The master of Hebraica veritas also prided himself on translation accomplished according to "sense" instead of "word." ${ }^{100}$ Like the superlative and authentic "Hebrewness" of the apostles-which is, in fact, an artifice and device-Jerome can connect his own knowledge and expertise to that Jewish genesis of Christianity without risking the taint of actual Jewishness.

We can perhaps understand, then, Jerome's incensed response to Augustine's suggestion that Peter and Paul truly debated the practice

\footnotetext{
${ }^{97}$ Jerome, Commentarius in Hieremiam 18.2 (31:15) (CCL 74:306-7).

${ }^{98}$ Jerome, Commentarius in epistolam ad Galatas 2.4.29-31 (PL 26:392).

${ }_{99}^{99}$ Jerome, Commentarius in Isaiam 17.64.4-5 (CCL 73A:735); cf. Commentarius in epistolam ad Galatas 2.3.14 (PL 26:363) and ep. 121.10.1-2 (CSEL 56:42-43).

${ }^{100}$ Jerome's translation theory (heavily dependent upon Cicero), inconsistently followed throughout his life, is laid out in his ep. 57, also known as De optimo genere interpretandi: the text is reproduced with commentary in G. J. M. Bartelink, Hieronymus: Liber de Optimo Genere Interpretandi (Epistula 57), ein Kommentar, Mnemosyne Bibliotheca Classica Batavia (Leiden: Brill, 1980). See also William Adler, "Ad verbum or Ad sensum: The Christianization of a Latin Translation Formula in the Fourth Century," in Pursuing the Text: Studies in Honor of Ben Zion Wacholder on the Occasion of his Seventieth Birthday, ed. J. C. Reeves and J. Kampen, Journal for the Study of the Old Testament Supplement Series 184 (Sheffield: Sheffield Academic Press, 1994), 321-48.
} 


\section{Paul and the Problem of Jewish Origins}

of Jewish ritual. For Paul actually to have embraced Judaism, as Augustine suggests, ${ }^{101}$ and not just the expert face of the "Hebrew of Hebrews," might suggest a similar Judaizing failure on Jerome's part: " $I$ shall say to the contrary, even if the whole world shouts me down in a single voice in response, that the ceremonies of the Jews are harmful and fatal to Christians, and that whoever observes them, whether from among the Jews or the gentiles, is cast down into the devil's pit!"102 This condemnation of the law must hold true for the apostles as well, even (indeed, especially) when they speak "as Hebraei ex Hebraeis." For Jerome, being a "Jew's Jew" was to be no Jew at all but rather an expert Christian: it was to mime and mimic and to demonstrate a masterful ability to know without becoming.

The anxiety provoked by Jerome's insistent Jewish ventriloquism not only inspired Augustine to write in concern to his curmudgeonly colleague, but also opened up Jerome to even more serious charges of theological "Judaizing." Jerome's erstwhile friend and schoolmate Rufinus, who became his bitter rival during the fourth-century Origenist controversy, turned Jerome's figure of Jewish ventriloquism on its head. ${ }^{103}$ Rufinus attacked Jerome for (among other things) daring to translate the Latin Scriptures anew iuxta Hebraeos. Rufinus saw this as a form of elitist impiety, rejecting the Septuagint which had served as faithful Christian Scriptures since the days of the apostles. ${ }^{104}$ What else, Rufinus asks, could have prompted Jerome's rejection of the Septuagint but Jerome's pernicious fascination with Jews? Rufinus pointed out that even the most Christian of apostles, Peter and Paul, while founding the church in Rome, did not find it necessary to tamper with or reject the Septuagint:

Did the apostle Peter deceive the church of Christ, and hand over to it falsified books containing nothing true [i.e., the Septuagint]? Even though he knew that the truth was possessed by the Jews, he wanted the Christians to have that which was falsified? But perhaps he says that Peter was illiterate. . . Let us concede that the apostle Peter could not have done it [i.e., retranslated the Septuagint iuxta Hebraeos]: Was Paul illiterate? He was a Hebrew of Hebrews, according to the Law a Pharisee, educated at the feet of Gamaliel, himself also

\footnotetext{
${ }^{101}$ According to Augustine, Peter's error, corrected by Paul, lay in coercing gentiles to "Judaize"; both apostles, in Augustine's view, appropriately continued to observe the Jewish law themselves, the view Jerome so vociferously rejects here. Both Jerome and Augustine, in this correspondence, deftly accuse the other of Judaizing.

${ }^{102}$ Jerome, ep. 112.17.2 (CSEL 55:387).

${ }^{103}$ Elizabeth A. Clark, The Origenist Controversy: The Cultural Construction of an Early Christian Debate (Princeton, NJ: Princeton University Press, 1992), 11-17, 121-51, and 159-93.

${ }^{104}$ Kamesar, Jerome, 19-21, relates Rufinus's preference for the Septuagint in opposition to Jerome's innovative translation iuxta Hebraeos.
} 
The Journal of Religion

stationed in Rome-if Peter was incapable, you don't think he [Paul] could have accomplished it? ${ }^{105}$

For Rufinus, Jerome's taking up of a "Jewish" voice does not demonstrate apostolic mastery, but rather hubris, impiety, and the abandonment of Christian faith in favor of Jewish deceit. For Rufinus, the fact that Paul was a "Jew's Jew" does not provide justification for Jerome's Hebrew mimicry but rather serves as a warning about the perils of religious boundary crossing: not even the apostles themselves thought it necessary, or prudent, to confront so audaciously the Jewish origins of true Christian faith.

\section{CONCLUSION}

As the variety of sources surveyed here suggest, wearing the Pauline mask of superlative "Hebrewness" was a risky rhetorical performance. It was an attempt to walk the fine boundaries of a dangerously unclear division between Judaism and Christianity, in a way that perhaps rendered those divisions even less clear than before. When John Chrysostom sought to lure away Christians who acted "too Jewishly" by himself speaking in the voice of Paul, a "Jew's Jew," members of his audience might not have found much distinction between John's Jewish speech and that of his Jewish-Christian opponents. Cyril's ability to speak both as Paul the Jew and as an anonymous, recalcitrant Jewish opponent could similarly destabilize the very boundaries Cyril seemed so intent on enforcing. Even when Paul's superlative Jewish voice was thrown onto other figures-such as Moses, Josephus, or the evangelists-the rhetorical dangers of a Christian ventriloquizing the voice of Jewish origins could be keenly felt. Indeed, as Rufinus's counteruse of the Pauline epithet "Hebrew of Hebrews" suggests, not all ancient Christians viewed the performance of Paul's exemplary Jewishness with the same sense of masterful appropriation as Jerome, Cyril of Alexandria, John Chrysostom, or Eusebius of Caesarea. Others, like Ambrosiaster, steeped in an anxiety of Jewishness that lingered at the heart of their sacred history, preferred to convert and transform that Jewishness altogether. For Ambrosiaster or Rufinus, to attempt to master Jewishness from within was to risk sliding down a precarious slope to becoming actual Jews.

I have drawn my examples from the fourth and fifth centuries, not only because of the "rise of Paul" evident in Christian exegetical circles evident during this period but also because we can perceive in these

${ }^{105}$ Rufinus, Apologia adversus Hieronymum 2.37 (CCL 20:112). 


\section{Paul and the Problem of Jewish Origins}

centuries new modes of Christian articulations of identity and difference. As the orthodox Christian world merged with the Roman Empire, so too, perhaps, did an early Christian insistence on radical distinction from "others" (Jews, pagans, heretics) begin to take on some of the strategies of Roman imperial power relations. As recent cultural studies of ancient Rome detail, the Romans did not eradicate or suppress difference, they managed it: like an arena filled with exotica from abroad, the Roman oikoumene was a display of imperial strength grounded precisely in the maintenance and appropriation of the different-and dangerous-within its borders. ${ }^{106}$ The early Christian appropriation of Jewishness, through the superlative Jewishness of the apostle Paul, might be read as an analogous and even more deeply aggressive management of difference: taking hold of the potentially confusing otherness at the origins of Christianity and choosing to master it rather than purge it.

The counterexamples of Rufinus and Ambrosiaster suggest that not all post-Constantinian Christians were comfortable managing difference in Roman imperial style, particularly with respect to Judaism. At

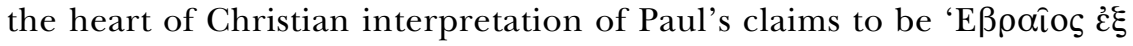

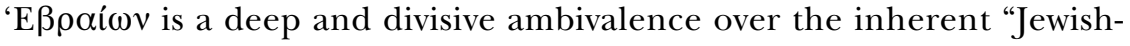
ness" of Christianity, an ambivalence echoed in contemporary debates over the historical and theological significance of the New Paul. Does Paul embrace the law, or reject it? Does he remain a Jew, or become something else? What does it mean for Christian self-definition that the apostle spoke as a "Jew's Jew"? James D. G. Dunn writes that Paul's Jewish boasting presents the reader with an "ambiguity and confusion" that "remains at the heart of Christian identity today and continues to haunt Jewish-Christian dialogue." 107 Or, as John Gager more succinctly puts it, "No one wants an apostle riddled with contradictions." 108

Yet for some Christians it has been this very ambiguity, the voice of Paul the riddler, that created such fertile ground for the production of Christian identities, past and present. For the ancient Christians of the Roman Empire I have presented here, Paul's ambiguity provided an experimental zone within which they might play with the tools of imperial confidence, putting on the voice of Jewish otherness like a gladiator donning a lionskin. This Jewish voice, though exemplary, was safely tempered by the apostle's unquestionable piety, offering a way

\footnotetext{
${ }^{106}$ See, e.g., Catharine Edwards and Greg Woolf, eds., Rome the Cosmopolis (Cambridge: Cambridge University Press, 2003); and Christopher A. Frilingos, Spectacles of Empire: Monsters, Martyrs, and the Book of Revelation (Philadelphia: University of Pennsylvania Press, 2004).

${ }^{107}$ Dunn, "Who Did Paul Think He Was?" 193.

${ }^{108}$ Gager, Reinventing Paul, 7.
} 


\section{The Journal of Religion}

out for those Christians troubled by the casual appropriation of Jewish difference. The appropriation of a Jewish voice has always been central to the construction of Christianity, ${ }^{109}$ often producing theological identities that refuse absolute resolution but continually push the limits of paradox and contradiction. Paul's doubled voice, Jewish and not-Jewish, apostle par excellence and Hebrew of Hebrews, creates a flexible framework within which Christians have been able to explore to great effect this internal contradiction and ambiguity. Yet Dunn and other New Perspective scholars are also right to point out the ethical dilemmas incumbent upon this Christian construction of a Jewish voice and the potential for misunderstanding and interreligious strife. In antiquity, such confrontation and argumentation was not the unfortunate consequence of the Christian appropriation of a superlative Jewish voice but rather the goal of this attempt to construct a theological self out of the haunting difference of the other.

\footnotetext{
${ }^{109}$ Consider, e.g., Hermann Strack and Paul Billerbeck's still influential Kommentar zum Neuen Testament aus Talmud und Midrasch (Munich: Beck, 1922-61), which has served generations of New Testament theologians otherwise unfamiliar with ancient Jewish texts as the authoritative voice of ancient Judaism.
} 